\title{
Inferno: colour Doppler ultrasound sign of orchitis
}

\author{
Suheil Artul ${ }_{1}^{1,2}$ Yousef Abu Rahmah, ${ }^{1}$ Hani Abu Shkara, ${ }^{1}$ Antoine Yamini ${ }^{1}$
}

Department of Radiology, EMMS Hospital Nazareth, Nazareth, Israel

${ }^{2}$ Faculty of Medicine, Bar Ilan University, Nazareth, Israe

\section{Correspondence to}

Dr Suheil Artul,

suheil_artul@hotmail.com

Accepted 4 March 2014

\section{DESCRIPTION}

A 19-year-old man presented to emergency department with acute scrotum of the left testis. On physical examination, it was difficult to distinguish clinically between testicular torsion and orchitis. Ultrasound of the scrotum showed normal echo texture of the right testis (figure 1) and enlarged hypoechoic left testis and an oedematous scrotum (figure 2). Doppler ultrasound showed increased, diffused colour of left testis that means increased vascularity and hyperaemia, the so-called Inferno sign (figure 3). The testicle recovered well after antibiotic treatment.

Acute scrotum is a urological emergency issue. Colour Doppler ultrasound can differentiate between surgical diseases such as torsion of testes and medical (non-surgical) entity such as orchitis. Inferno sign is a possible Doppler ultrasound sign of infection such as orchitis.

Acute scrotum is always a dilemma for the referring clinician and for the radiologist performing ultrasound. Using ultrasound alone without using colour Doppler does not always permit the achievement of a final diagnosis. ${ }^{1}$

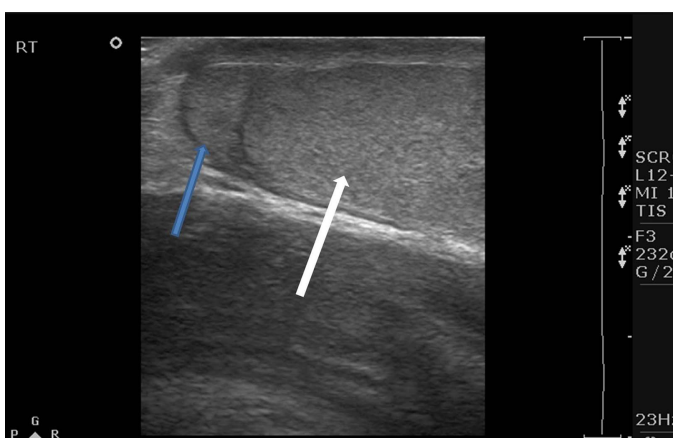

Figure 1 Longitudinal ultrasound of the right scrotum showing normal echo texture of the testis (white arrow) and normal epididymis (blue arrow).

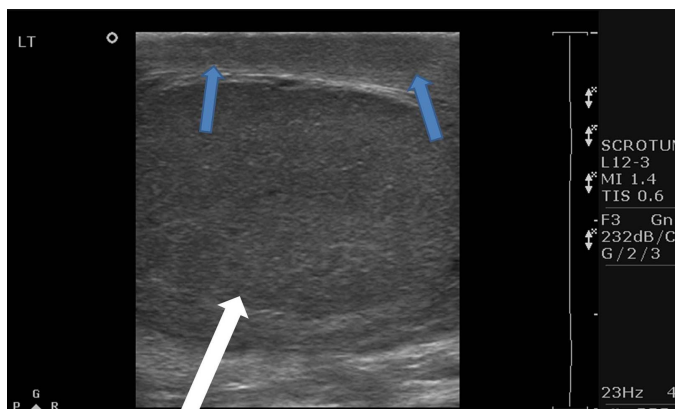

Figure 2 Longitudinal ultrasound of the left testis showing enlarged, hypoechoic testes (white arrow) and oedematous scrotum (blue arrows).

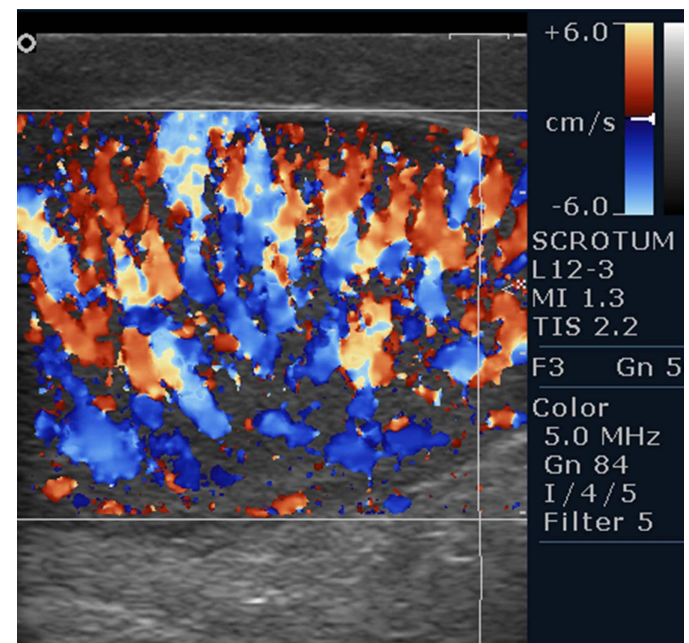

Figure 3 Colour Doppler ultrasound of the left testis showing inferno sign.

Grey scale signs such as hypoechogenecity and enlarged testis are not specific, and these two signs alone cannot always differentiate between torsion

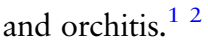

Inferno sign was first described as a sign of thyroiditis, and has never been described before as a sign of orchitis.

However, hypervascularity of the epididymis without hypervascularity of the testes itself could be a sign of torsion.

We think that this sign is also a sign of orchitis and must be mentioned when present while evaluating a patient with acute scrotum.

\section{Learning points}

- In acute scrotum, we have to differentiate between torsion and orchitis.

- Inferno is a possible sign of orchitis.

- Grey scale signs are not always specific for differential diagnosis of acute scrotum.

Competing interests None

Patient consent Obtained.

Provenance and peer review Not commissioned; externally peer reviewed.

\section{REFERENCES}

1 Artul S, Fahoum B, Khoury R, et al. Pack of ice: gray scale sign of testicular torsion. BMJ Case Rep. Published online: 15 Jan 2014. doi:10.1136/bcr-2013-202734

2 Dogra VS, Gottlieb RH, Oka M, et al. Sonography of the scrotum. Radiology 2003;227:18-36. 


\section{Images in...}

Copyright 2014 BMJ Publishing Group. All rights reserved. For permission to reuse any of this content visit http://group.bmj.com/group/rights-licensing/permissions.

BMJ Case Report Fellows may re-use this article for personal use and teaching without any further permission.

Become a Fellow of BMJ Case Reports today and you can:

- Submit as many cases as you like

- Enjoy fast sympathetic peer review and rapid publication of accepted articles

- Access all the published articles

- Re-use any of the published material for personal use and teaching without further permission

For information on Institutional Fellowships contact consortiasales@bmjgroup.com

Visit casereports.bmj.com for more articles like this and to become a Fellow 